\title{
Comparison of Protein Composition of Normal and Quality Protein Maize
}

\author{
Poonam Choudhary $^{1 *}$ and Dharam Paul Chaudhary ${ }^{2}$ \\ ${ }^{1}$ ICAR-Central Institute of Post-Harvest Engineering and Technology, \\ Ludhiana, Punjab, India \\ ${ }^{2}$ ICAR-Indian Institute of Maize Research, PAU Campus, Ludhiana, Punjab, India \\ *Corresponding author
}

\section{A B S T R A C T}

\begin{tabular}{|c|}
\hline Keywords \\
\hline $\begin{array}{l}\text { Maize, Protein } \\
\text { fractionation, } \\
\text { Quality protein } \\
\text { maize, Tryptophan } \\
\text { and Zeins }\end{array}$ \\
\hline Article Info \\
\hline $\begin{array}{l}\text { Accepted: } \\
28 \text { November } 2020 \\
\text { Available Online: } \\
10 \text { December } 2020\end{array}$ \\
\hline
\end{tabular}

\begin{abstract}
The endosperm of normal maize is predominates with the zein proteins (prolamins and prolamin-like) which are primarily responsible for poor quality of protein. To overcome such problems researchers have developed quality protein maize (QPM) by modifying the protein profile of normal maize so the present study was taken up to understand the comparative protein composition in kernels of normal and quality protein maize. For this purpose six maize genotypes were evaluated for tryptophan content, endosperm protein and protein fractions viz. albumin and globulins, prolamins, prolamin-like, glutelin-like and glutelins. Approximately 47\% higher tryptophan content was observed in QPM genotypes which are result of endosperm modification that alter maize endosperm amino acid profile and composition of maize endosperm protein. In addition, QPM genotypes also had higher albumin, globulins and glutelins fractions as compared to the normal maize. The normal genotypes showed approximately $60 \%$ of total protein as zein protein as compared to QPM genotypes having 30\% of total protein as zein protein. The presence of opaque-2 gene in QPM genotypes, encodes a transcription factor which reduces the transcription and expression of $22 \mathrm{kD}$ alpha-zein protein and increases the non-zein protein fractions. It was concluded that QPM maize possess an improved amino acid profile and endosperm protein composition which ensures the nutritional security.
\end{abstract}

\section{Introduction}

Maize (Zea mays L.) popularly known as corn, is one of the most useful emergent cash crops. It is also known as "queen of cereals" globally. The crop has tremendous genetic variability, which enables it to thrive in tropics, sub-tropics and temperate climates. In India, it is the third most essential food cash crops after wheat and rice. Maize is grown throughout the year to provide nutrients and feed for humans and animals and also serve as a raw material for thousands of industries including food sweeteners, pharmaceutical, alcoholic beverages, cosmetics and fuel etc. In India, maize is grown to meet demands of various sectors as it provides about $47 \%$ as poultry feed, $20 \%$ as direct consumption, $14 \%$ as livestock consumption, $12 \%$ as starch production, $7 \%$ as food processing, brewery and others. The normal maize possesses approximately $8-13 \%$ protein, $68-73 \%$ starch, 2-3\% oil, 2-4\% sugar with rest of the material being provided by fibre and minerals 
etc. (Balconi et al., 2007). Endosperm is the store house of seed storage proteins. Maize is considered as nutritionally poor because of deficiencies of tryptophan and lysine, the essential amino acids. A balanced protein is required to assist body building process and therefore, amino acid balance seems to be a determining factor for quality of any food and feed. In the normal maize endosperm, zeins proteins are predominates, which are primarily responsible for poor quality of protein. The major fraction $(60 \%)$ of seed protein in maize is zeins (a prolamin groupalcohol soluble) (Leite et al., 1999) followed by glutelin (34\%), while albumin and globulin occur in traces (3\% each). To overcome such problems researchers have developed quality protein maize by modifying the protein profile of maize.

Quality protein maize is characterized by higher content of non-zeins, which are better in terms of protein quality. Keeping this in mind, the present experiment was planned to understand the protein composition of normal and quality protein maize genotypes. For this purpose the endosperm protein and tryptophan content estimated and also fractionated the endosperm protein into different fractions viz. albumin and globulins, prolamins, prolamin-like, glutelin-like and glutelins at Biochemistry laboratory, IIMR, PAU campus, Ludhiana.

\section{Materials and Methods}

Six maize genotypes were selected for the protein profiling of normal and QPM. The material details are given in table below.

All genotypes were grown at Ladhowal farm of IIMR, Ludhiana. The genotypes were grown simultaneously. Samples were taken after harvesting of crop. The samples were dried in shade followed by drying in hot air over at $100{ }^{\circ} \mathrm{C}$ and used for analysis.

\section{Endosperm Separation}

The protein quality of maize endosperm is poor as compared to the embryo so determination of endosperm protein is useful for comparative protein composition of normal and quality protein maize.

For endosperm separation, the seeds of maize were soaked in distilled water for overnight and the pericarp and germ content was removed using scalpel. The seeds were ground to fine powder (80-100 mesh) by using lab mill and de-fatted in petroleum ether for 3 days and finally kept in desiccators for drying the samples.

\section{Determination of crude protein}

Crude protein was determined by MicroKjeldahl method of AOAC (1970). In this method, the $100 \mathrm{mg}$ sample containing $1 \mathrm{~g}$ of catalyst mixture was digested in $5 \mathrm{ml}$ concentrated sulphuric acid at $370{ }^{\circ} \mathrm{C}$ until the solution became colourless. After that distillation and titration were done by using sodium hydroxide and $0.02 \mathrm{~N} \mathrm{HCl}$. The nitrogen and protein content were calculated following the formula:

Nitrogen content is determined as:-

$$
\mathrm{N}(\%)=\frac{1.4007\left(\mathrm{~V}_{2}-\underline{\mathrm{V}}_{1}\right) \mathrm{N} \times 100}{\mathrm{~W}}
$$

Crude protein percentage is calculated as:-

$\mathrm{P}(\%)=\mathrm{N}(\%) \times$ Protein factor

Note:- 6.25 is protein factor published by American association of cereal chemist (AACC)

\section{Protein fractionation}

Protein fractionation procedure as given by Landry and Moureaux (1970) separates 
protein into five fractions namely: albumins + globulins, prolamins, prolamin-like, glutelin-

like and true glutelins are obtained by following the scheme described herein.

\begin{tabular}{|c|c|c|c|c|}
\hline Fraction & Solvent & $\begin{array}{l}\text { Extraction } \\
\text { Temp }\end{array}$ & $\begin{array}{c}\text { Time of } \\
\text { agitation (min) }\end{array}$ & $\begin{array}{l}\text { Protein } \\
\text { fraction }\end{array}$ \\
\hline \multirow[t]{5}{*}{ I } & \multirow[t]{3}{*}{$\mathrm{NaCI}, 0.5 \mathrm{M}$} & \multirow[t]{5}{*}{$4{ }^{\circ} \mathrm{C}$} & 60 & \multirow{5}{*}{$\begin{array}{l}\text { Albumins and } \\
\text { Globulins }\end{array}$} \\
\hline & & & 30 & \\
\hline & & & 30 & \\
\hline & \multirow[t]{2}{*}{ Water } & & 15 & \\
\hline & & & 15 & \\
\hline \multirow[t]{3}{*}{ II } & \multirow[t]{3}{*}{ Isopropanol, 70\% } & \multirow[t]{3}{*}{$20{ }^{\circ} \mathrm{C}$} & 30 & \multirow[t]{3}{*}{ Prolamin } \\
\hline & & & 30 & \\
\hline & & & 30 & \\
\hline \multirow[t]{2}{*}{ III } & \multirow{2}{*}{$\begin{array}{l}\text { Isopropanol, } 70 \% \\
+2-\mathrm{ME}, 0.6 \%(\mathrm{v} / \mathrm{v})\end{array}$} & \multirow[t]{2}{*}{$20^{\circ} \mathrm{C}$} & 30 & \multirow[t]{2}{*}{ Prolamin-like } \\
\hline & & & 30 & \\
\hline \multirow[t]{3}{*}{ IV } & \multirow{3}{*}{$\begin{array}{c}\text { Borate buffer, 0.05 M } \\
\mathrm{pH} 10+2-\mathrm{ME}, 0.6 \%(\mathrm{v} / \mathrm{v})\end{array}$} & \multirow[t]{3}{*}{$20^{\circ} \mathrm{C}$} & 60 & \multirow[t]{3}{*}{ Glutelin-like } \\
\hline & & & 30 & \\
\hline & & & 15 & \\
\hline \multirow[t]{3}{*}{ V } & \multirow{3}{*}{$\begin{array}{l}\text { Borate buffer } \mathrm{pH} 10 \\
+2-\mathrm{ME}, 0.65(\mathrm{v} / \mathrm{v}) \\
+ \text { SDS, } 0.5 \%(\mathrm{w} / \mathrm{v})\end{array}$} & \multirow[t]{3}{*}{$20^{\circ} \mathrm{C}$} & 60 & \multirow[t]{3}{*}{ Glutelin } \\
\hline & & & 30 & \\
\hline & & & 15 & \\
\hline
\end{tabular}

For protein fractionation $2 \mathrm{~g}$ of de-fatted finely ground (100 mesh) sample was taken in a stoppered centrifuge tube and $20 \mathrm{ml} 0.5 \mathrm{M}$ $\mathrm{NaCl}$ solution was added to it. The content was agitated for $60 \mathrm{~min}$ at $4^{\circ} \mathrm{C}$ and centrifuged at $6000 \mathrm{x} \mathrm{g}$ for $5 \mathrm{~min}$. The supernatant was polled into beaker and the residue was re-agitated twice for $30 \mathrm{~min}$ each with $0.5 \mathrm{M} \mathrm{NaCl}$ and again pooled the supernatant. Then the residue was further extracted twice by using distilled water in the same manner. All the supernatants were collected and the final volume was made upto $100 \mathrm{ml}$ with saline. This represented fraction I which contained albumins and globulins. Following the same procedure prolamins, prolamin-like, glutelin-like and glutelins were extracted from the residue obtained after completion of fraction I. The residue obtained at the last extraction was analyzed and represented as residue protein (insoluble protein). For the determination of albumins and globulins from fraction I, equal volume of $10 \%$ tri chloro acetic acid was added and allowed it to remain in cold for $30 \mathrm{~min}$ then centrifuged at $6000 \mathrm{x} \mathrm{g}$ for $15 \mathrm{~min}$ at $4{ }^{\circ} \mathrm{C}$.
The precipitate obtained represents albumins + globulins, while the supernatant will contain non-protein nitrogen (free amino acids and peptides). After that nitrogen was estimated in all the fractions after digestions and distillation by Micro-Kjeldahl method.

\section{Estimation of tryptophan content by papain hydrolysis method}

Tryptophan content was determined by the method of Spies and Chambers (1949). The $100 \mathrm{mg}$ of de-fatted maize endosperm sample was weighed into a glass vial and freshly prepared $4 \mathrm{ml}$ papain solution was added to it. After that the vial was capped and shaken properly and kept in an incubator at $65{ }^{\circ} \mathrm{C}$ overnight for hydrolysis. Sample was shaken one hour after putting and one hour before taking out from the incubator. The hydrolysed sample was removed from the incubator, shaken and allowed to cool in order to make the supernatant clear. One $\mathrm{ml}$ of hydrolysed sample upper layer was pipette out in a test tube containing $4 \mathrm{ml}$ of reagent $\mathrm{C}$. The mixture was then shaken vigorously using vortex mixer. After that the tubes were kept 
for 15 minutes in an incubator at $65{ }^{\circ} \mathrm{C}$ for colour development. After cooling, the solution was transferred to calibrated tubes. The O.D against the blank was recorded at $545 \mathrm{~nm}$. The tryptophan content was calculated in the samples using the standard curve of 0 to $40 \mathrm{ug} / \mathrm{ml}$ of DL-tryptophan and reported on a protein basis.

\section{Statistical analysis}

Analysis of Variance (ANOVA) was performed following a factorial complete block design. Means and sources of variance were analysed using the $\mathrm{SAS}^{\circledR}$ statistical package (SAS Institute, 1989). Analyses were carried out in triplicate.

\section{Results and Discussion}

The protein and tryptophan in protein were analysed in 6 inbred lines and the results were presented in Table 2. The range of protein content was from 8.37 to 12.80 per cent with the lowest and highest values being exhibited by the genotypes CML-266 and LM-11-288 respectively. Tryptophan content in protein varied from 0.41 to 0.76 per cent. Tryptophan and lysine are two limiting amino acids in normal maize. The nutritional quality of normal maize is poor because of deficiencies of these two essential amino acids. The QPM genotypes had approximately double tryptophan in protein as compared to the normal genotypes.

Table.1 Maize genotypes selected for protein quality analysis

\begin{tabular}{|l|l|l|}
\hline S. No. & Genotypes & Type of maize \\
\hline 1 & DQL-1001 & \\
\hline 2. & DQL-1019 & Quality Protein Maize \\
\hline 3. & LM-11-288 & \\
\hline 4. & LM-12 & \\
\hline 5. & CML-172 & Normal maize \\
\hline 6. & CML-266 & \\
\hline
\end{tabular}

Table.2 Crude protein and tryptophan content in the endosperm of normal and QPM maize genotypes

\begin{tabular}{|l|c|c|}
\hline Genotypes & Crude protein $(\%)$ & Tryptophan (\% Protein) \\
\hline DQL-1001 & 8.40 & 0.60 \\
\hline DQL-1019 & 9.58 & 0.76 \\
\hline LM-11-288 & 12.80 & 0.48 \\
\hline LM-12 & 10.22 & 0.41 \\
\hline CML-172 & 10.83 & 0.42 \\
\hline CML-266 & 8.37 & 0.46 \\
\hline
\end{tabular}


Table.3 Protein fractions in the endosperm of normal and QPM maize genotypes

\begin{tabular}{|l|c|c|c|c|c|c|}
\hline Protein fraction & \multicolumn{6}{|c|}{ Maize genotypes } \\
\cline { 2 - 7 } & $\begin{array}{l}\text { DQL- } \\
\text { 1001 }\end{array}$ & $\begin{array}{l}\text { DQL- } \\
\mathbf{1 0 1 9}\end{array}$ & $\begin{array}{l}\text { LM-11- } \\
\mathbf{2 8 8}\end{array}$ & LM-12 & CML-172 & CML-266 \\
\hline Albumin(\%) & 0.67 & 0.70 & 0.18 & 0.32 & 0.15 & 0.23 \\
\hline Globulin(\%) & 0.70 & 0.90 & 0.60 & 0.24 & 0.14 & 0.18 \\
\hline Prolamins (\%) & 1.70 & 2.03 & 6.04 & 4.48 & 5.18 & 3.64 \\
\hline Prolamin-like (\%) & 0.84 & 1.00 & 1.32 & 1.03 & 1.65 & 1.31 \\
\hline Glutelin-like (\%) & 0.66 & 0.71 & 0.60 & 0.60 & 0.73 & 0.61 \\
\hline Glutelin (\%) & 2.12 & 2.39 & 2.35 & 2.05 & 1.80 & 1.36 \\
\hline Residue (\%) & 1.14 & 1.47 & 1.25 & 0.82 & 1.12 & 1.06 \\
\hline
\end{tabular}

Table.4 Total recovered protein (\%) in the endosperm of normal and QPM maize genotypes

\begin{tabular}{|l|c|c|c|c|c|c|}
\hline \multirow{2}{*}{ Protein fraction } & \multicolumn{7}{|c|}{ Maize genotypes } \\
\cline { 2 - 7 } & DQL- & DQL- & LM-11- & LM-12 & CML-172 & CML-266 \\
\hline Albumin (\%) & $\mathbf{1 0 0 1}$ & $\mathbf{1 0 1 9}$ & $\mathbf{2 8 8}$ & & & \\
\hline Globulin (\%) & 7.92 & 7.30 & 1.37 & 3.14 & 1.39 & 2.75 \\
\hline Prolamins (\%) & 8.46 & 9.40 & 4.63 & 2.14 & 1.25 & 2.09 \\
\hline Prolamin-like (\%) & 9.18 & 21.19 & 47.19 & 43.84 & 47.79 & 43.49 \\
\hline Glutelin-like (\%) & 7.86 & 10.44 & 10.31 & 10.03 & 15.23 & 15.08 \\
\hline Glutelin (\%) & 25.24 & 24.91 & 4.73 & 5.87 & 6.74 & 7.21 \\
\hline Residue (\%) & 13.57 & 15.34 & 18.36 & 20.01 & 16.57 & 16.19 \\
\hline Loss in recovery (\%) & 6.78 & 3.97 & 3.66 & 7.98 & 10.30 & 12.67 \\
\hline
\end{tabular}

Seed proteins have been classified into five major groups based on their solubility. These include: water soluble albumins, salt soluble globulins, alcohol soluble prolamins, and alkali soluble glutelins and residue (insoluble) proteins. Although solubility is one of the classic criteria for separating seed proteins, it is not an ideal classification as the solubility is critically dependent on a number of conditions like the exact nature of the solvent, the ratio of solvent to sample, the hydration state of sample, the temperature of the solvent, fineness of the sample, etc. The distributions of endosperm protein into the different fractions were presented in Table 3. The normal genotypes had almost twice the zein fraction as compared to the QPM genotypes. The genotypes DQL-1001, DQL-
1019 had the highest albumin, globulins and glutelin fractions and the lowest zein fractions as compared to the other genotypes. The prolamins and prolamin-like fractions represent the zein protein which is responsible for the nutritionally poor maize whereas the presence of opaque-2 gene in QPM genotypes reduced the synthesis of $22 \mathrm{kD}$ alpha-zein and increases the synthesis of non-zein protein fractions, particularly glutelins resulting in increased tryptophan and lysine in endosperm protein (Holding et al., 2011, Sofi et al., 2009, Gibbon and Larkin 2005). The total recovered protein fractions from endosperm of six maize genotypes were presented in the Table 4. It is found that the genotype DQL1001 (QPM) had $16.38 \%$ albumin and globulins, $30.17 \%$ prolamins $33.1 \%$ glutelins 
and $13.57 \%$ residue whereas the other genotype CML-266 which is normal genotype had $4.84 \%$ albumin and globulins, $58.57 \%$ prolamins, $23.40 \%$ glutelins and $12.67 \%$ residue, respectively.

However, from this study it is concluded that the protein distribution in the endosperm of normal and QPM genotypes varied significantly and the normal genotypes had the lower tryptophan in protein with the higher content of zein proteins which suppressed the level of tryptophan and lysine in the normal maize endosperm whereas in the QPM genotypes the reduced expression of $22 \mathrm{kD}$ alpha-zein protein increases the nonzein protein fractions and also improves the level of lysine and tryptophan amino acids.

\section{References}

Association of Official Analytical Chemists AOAC (1970).Official Methods of Analysis, AOAC, Washington, D.C.

Balconi C, Lanzanova C, Conti E, Triulzi T, Forlani F, Cattaneo M and Lupotto E. (2007). Fusarium head blight evaluation in wheat transgenic plants expressing the maize b-32 antifungal gene. European Journal of Plant Pathology 117: 129-40.

Gibbon B. and Larkin B (2005). Molecular genetic approaches to developing quality protein maize. Trends Genetics, 21:227-233.

Holding, D. R., Hunter, B. G., Klingler, J. P.,
Wu, S., Guo, X. M., Gibbon, B. C., Wu, R. L., Schulze, J. M., Jung, R. and Larkin, B. A. (2011). Characterization of opaque2 modifier QTLs and candidate genes in recombinant inbred lines derived from the K0326Y quality protein maize inbred. Theoretical and Applied Genetics, 122: 783-794.

Landry J. and Moureaux T. (1970). Heterogeneite des glutelines du grain de maize:Extraction selective et composition en acides amines des trois fractions isolees. Bull Soc Chim Biol 52: 1021-1037

Leite A, Neto GC, Vettore AL, Yunes JA \& Arruda P (1999) The prolamins of sorghum, Coix and millets. In: Shewry PR \& Casey R (Eds) Seed proteins. Dordrecht. Kluwer Academic Publishers, pp. 141-157.

SAS Institute 1989. SAS/STAT User's Guide, ver. 6, vol. 2, 4th ed. SAS Institute, Cary, N.C.

Sofi P. A.,Wani S. A, Rather A. G. and. Wani S. H. (2009). Quality protein maize (QPM): Genetic manipulation for the nutritional fortification of maize. Journal of Plant Breeding and Crop Science, 1(6): 244253.

Spies, J. R. and Chambers D. C. (1949). Chemical determination of tryptophan in proteins. AnalyticalChemistry 21:1249-1266.

\section{How to cite this article:}

Poonam Choudhary and Dharam Paul Chaudhary. 2020. Comparison of Protein Composition of Normal and Quality Protein Maize. Int.J.Curr.Microbiol.App.Sci. 9(12): 3297-3302. doi: https://doi.org/10.20546/ijcmas.2020.912.392 